\title{
THE RESISTANCE OF WOOD PLASTIC COMPOSITE TO THE DRY-WOOD TERMITE Cryptotermes cynocephalus Light. AND THE SUBTERRANEAN TERMITE Coptotermes curvignathus Holmgren INFESTATION.
}

\author{
Jasni $^{1}$, Nurwati Hadjib ${ }^{1}$, Barly $^{1}$, Yusuf S. Hadi ${ }^{2}$ and Y. Afidudin ${ }^{2}$
}

\begin{abstract}
Wood plastic composites (WPC) were made by impregnating monomer and vinyl acetate monomer with addition of terbutyl peroxide catalyst. This laboratory scale experiment aimed at looking into the durability of WPC polymerized at varying mixture ratios between styrene and vinyl acetate monomers, compared to the natural durability of the corresponding wood treated with impralit $\mathrm{CKB}$. In this regard, wood samples were dried until $10 \%$ moisture content, and then they were put in the tank under $20 \mathrm{~mm}$ Hg vacuum was being released. Styrene monomer with vinyl acetate addition was flown to the tank, and the wood samples were immersed in the monomer for 24 hours. Furthermore, the wood samples were taken out, and wrapped with aluminum foil, and then were put in the oven for 24 hours at $60^{\circ} \mathrm{C}$. The wraps were opened, and the samples were conditioned. The samples were tested to dry wood termite (Cryptotermes cynocephalus Light.), and the Subterranean termite (Coptotermes curvignathus Holmgren.). Investigated factors were (i) wood species consisting of sengon, pine, and rubber wood, and (ii) ratio of styrene to vinyl acetate. i.e. $90 / 10 ; 80 / 20 ; 70 / 30$; and $60 / 40$. For comparison, each wood samples treated with Impralit CKB 3\% and untreated (unpolymerized) wood samples (a control) were also prepared. The results showed that polymer loadings in the sengon, pine and rubber wood were $118 \%, 72 \%$ and $44 \%$ respectively. Increasing of vinyl acetate to styrene tended to decrease polymer loading, the addition of $10 \%$ gave $96 \%$ polymer loading, $20 \%$ gave $108 \%, 30 \%$ gave $71 \%$, and $30 \%$ gave $38 \%$ respectively. It appeared that treatment of styrene with low vinyl acetate additions (60:40) had resulted in consecutively $95.67 \%$ and $97.75 \%$ mortality of the dry wood termite and sub subterranean termite. This implied that the treatment might increase the wood resistance to the wood destroying insect.
\end{abstract}

Keywords: Wood Plastic Composite (WPC),termites, durability, Impralit CKB

\section{INTRODUCTION}

Industrial Plantation Forest (IPF) has been developed for additional log supply in Indonesia. The target of IPF is 6 million ha, but until 1999 only 2.2 million ha of fast growing species have been planted, e.g sengon (Paraserianthes falcataria (L. Nielsen), pine (Pinus merkusii Jungh et. de V.), and rubber-wood (Hevea brassiliensis Muel.Arg.) The disadvantage of fast growing species is blamed on their inferior physical and mechanical properties, composed of the ordinary structural wood of the convensionally growing species. Polystyrene impregnation may be applied to increase physical and mechanical properties, so the wood of fast growing species can be more resistant to bio-deterioration attack as well.

1 Forest Products Research and Development Center, Bogor

2 Bogor Agriculture University, Bogor 
Wood is one of the materials, which has a close association with human needs, such as , household items, craft, and art articles. Besides, certain wood species may be regarded as highpriced values when being sold due to its advantageous characteristics, such as high natural durability and beautiful patterns. Wood with reliable durability can become one of the essential considerations for the users to select the durable wood species with respect to their proper utilization. Unfortunately, the supply of wood species with high durability nowadays is no longer adequate to meet the demand by their users. Meanwhile, wood species with low durability are abundantly available and yet still remain unutilized.

Low-durability wood species are susceptible against wood-destroying organisms thereby it necessitates effective preservation methods to improve their durability and hence increase their uses. One method is modifying wood properties with impregnation particular chemical agents into the porous wood structure, by filling-up its lumen, vessels, as well as the void spaces inside its cell walls. 'The modified products that result from this impregnation process are famously called as WPC (Wood Plastic Composite), where its physical, mechanical, and durability characteristics are greatly affected by types of monomers impregnated into wood structure as well as the species of wood themselves.

Previous investigation on WPC has been conducted using styrene monomer as the impregnating agent, and the polymeration reaction was enhanced using radiation with gamma ray or electron spectrum (Dirgantara,1988; Sajidin,1977; Susanti,1997) Unfortunately, this radiation technique is still regarded as expensive. Therefore. the use of styrene monomer alone may require costly processing expenses, which are further exacerbated by the limited availability of related instrument. The use of another type of impregnating agent, i.e. vinyl acetate monomer mixed with styrene monomer prior to its impregnation into wood structure can be an alternative to reduce the production cost of WPC using styrene alone, since, it minimizes the consumption of the latter monomer. Moreover, the polymerization reaction (and perhaps co-polymerration between styrene and vinyl acetate monomers) and its completion can be performed using a conventional manner (i.e. thermal or oven heating) which is much cheaper than the radiation techniques. This paper deals with efforts to increase the durability of wood against deteriorating organisms, especially the attack from subterranean termite (Coptotermes curvignathus Holmgren) as well as dry wood termite (Cryptotermes cynocephalus Light.), by modifying it into WPC using the mixture of styrene and vinyl acetate monomers at varying proportion. The aim of this investigation is to evaluate the durability of this resulting WPC.

\section{MATERIALS AND METHODS}

\section{A. Materials}

Wood species used in this investigation were sengon, pine/tusam, and rubber-wood. Meanwhile, the chemicals were styrene monomer, vinyl acetate monomer, terbutyl and peroxide catalyst. The organisms used were subterranean termite and dry wood termite 


\section{B. Methods}

\section{The manufacture/polymeration of wood-plastic composite (WPC)}

Samples of wood specimens were investigated using sengon, pine, and rubber wood species. There were two sizes of wood specimens, i.e. $5.0 \mathrm{~cm}$ (length) by $2.5 \mathrm{~cm}$ (width) by $1.5 \mathrm{~cm}$ (thickness, as growing media for dry wood termites) and $2.5 \mathrm{~cm}$ (length) by $2.5 \mathrm{~cm}$ (width) by $0.5 \mathrm{~cm}$ (thickness, for subterranean termite). Prior to the infection by subterranean as well as dry wood termites, firstly, the wood specimens were oven-dried and then co-polymerized into WPC using the mixture of styrene and vinyl acetate monomers as the impregnation agent. The mixture between the former and the latter monomers were made into 4 various proportions. i.e. $60: 40,70: 30,80.20$ and $90: 10$. To assist the co-polymerization reaction, each proportion was added with terbutyl catalyst. The co-polymerization into WPC for each mixture proportion was performed on wood specimens using the thermal method and replicated four times by allocating each for one specimen. For the comparison, as many as unpolymerized wood sample, each corresponding species were treated with Impralit CKB $3 \%$. In all, performing complete co-polymerization on wood samples incorporating the 4 varied mixture proportion and the 4 replication resulted in as many as 4 times 4 or 16 co-polymerized wood samples (WPC) for each corresponding wood species (i.e. sengon, pine, and rubber wood). Besides, as many as 4 unpolymerized wood samples from each corresponding species were also prepared as a control. The WPC, Impralit CKB treated wood samples, and the control were examined from their particular properties (i.e. durability).

\section{Testing on WPC durability}

The durability testing of WPC specimens was conducted and evaluated by infecting them with either subterranean termite or dry wood termite so was for the unpolymerized wood samples.

Evaluation using dry wood termite. In this regard, the WPC samples as polymerized from wood specimens (i.e. sengon, pine, and rubber-wood species) and as unpolymerized wood specimens of the corresponding species with the size of $5.0 \mathrm{~cm}$ by $2.5 \mathrm{~cm}$ by $1.5 \mathrm{~cm}$ were infected by the dry wood termite in the following manner. On the greatest width of the WPC samples as well as of unpolymerized wood specimens was placed a glass tube vertically with the diameter of $1.8 \mathrm{~cm}$ and height of $3.0 \mathrm{~cm}$. Further, into the glass tube were put as many as 50 dry wood termite to worker types. Afterward, the infected-WPC samples as well as-unpolymerized wood specimens were placed into a dark room and then were kept for 12 weeks.

Evaluation using subterranean termite. Rather different from the one using dry termite, each WPC specimen with size of $2.5 \mathrm{~cm}$ by $2.5 \mathrm{~cm}$ by $0.5 \mathrm{~cm}$ were put into a bottle. then placed as much as 200 gram of wet sand with its moisture content about 7 percent (approximately under its water-holding capacity). About 200 subterranean termite of worker types were put into each bottle which had been contained with sand and WPC samples as well as unpolymerized wood specimens. Every week, activity of the termites was observed and assessed by weighing the termites-infected WPC samples and infected unpolymerized wood specimens. When the moisture content of the sand dropped by $2 \%$ or so, some adequate amount of water was added into the bottle to restore its moisture content to the formed level. 


\section{Observation}

The responses were observed based on durability of WPC samples as well as unpolymerized wood specimens against the attack of termites including mortality of the termites and weight loss of the samples. The data on the resulting weight loss were further compared to durability class of wood as conceived by Supriana and Howse (1982) in Martawijaya (1996), and Sornuwat (1996), as follows:

Table 1. Durability class of wood according to Supriana dan Howse (1982) as cited by Martawijaya (1996)

\begin{tabular}{|c|l|c|c|}
\hline \multirow{2}{*}{ Class } & \multirow{2}{*}{ Resistance } & \multicolumn{2}{|c|}{ Weight loss (mg), due to the attacked by } \\
\cline { 3 - 4 } & & Cryptotermes cynocephalus Light. & Coptotermes curvignathus Holmgren. \\
\hline I & Resistant & $0-25$ & $0-50$ \\
\hline II & Moderately resistant & $26-50$ & $51-100$ \\
\hline III & Non - resistant & $51-75$ & $101-200$ \\
\hline IV & Susceptible & $>75$ & $>200$ \\
\hline
\end{tabular}

Table 2. Durability class of wood based on Sornuwat (1996)

\begin{tabular}{|c|c|}
\hline Percent of weight loss $(\%)^{*}$ & Level of resistance \\
\hline 0 & Highly resistant \\
\hline $1-3$ & Resistant \\
\hline $4-8$ & Moderately resistant \\
\hline $9-15$ & Non-resistant \\
\hline$>15$ & Susceptible \\
\hline
\end{tabular}

*) Modified wood block test .

For particular WPC samples, observation was performed based on their retention and loading of the plastic polymer (i.e. possible results of co-polymerization between styrene monomer, vinyl acetate monomer, and certain chemical wood compounds). Further observation was determination of protection degree of WPC samples as well as unpolymerized wood specimens against termite, which was subsequently compared to the scoring assessment.

Table 3. Scoring system to assess the protection level of wood against termite

\begin{tabular}{|l|c|}
\hline \multicolumn{1}{|c|}{ The condition of attacked wood } & Scoring (rating) system \\
\hline Sound & 100 \\
\hline Light attack & 90 \\
\hline Moderate attack & 70 \\
\hline Heavy attack & 40 \\
\hline Failure & 0 \\
\hline
\end{tabular}

Resource : AWPA, 1972

\section{Data analysis}

In order to assist the data interpretation, the nested analysis was employed with two successive factors. The first factor was wood species (i.e. rubber wood, sengon and fine/tusam), while the subsequent or second factor was the weight rations between styrene and vinyl acetate monomers (i.e. 60:40, 70:30, 80:20, 90:10). The second factor included impralit CKB treated wood and unpolymerized wood (as control). Each experimental units was replicated four times. 


\section{RESULTS AND DISCUSSION}

\section{A. Retention and Polymer Loading in The WPC Products}

The data on such retention and loading were evaluated using the analysis of variance (Table 4). The analysis further showed that the effect of different wood species and different mixture proportions between styrene and vinyl acetate monomers was significant on the retention and loading of the resulting plastic co-polymers in the WPC, allocated for the infecting media for the dry as well as subterranean termite. The detailed depiction was subsequently evaluated using the Duncan's multiple range test (Table 5). Both Table 4 and 5 indicates that the changes in the proportion of styrene monomers as mixed with vinyl acetate monomers significantly influenced the retention and loading of the resulting Co-polymerization between these two monomers. However, the characteristics were different among WPC products, depending on wood species.

This revealed that the penetration of styrene and vinyl into WPC was affected by wood species, since certain wood species could have their own specific anatomical characteristics and other related particular properties (Mandang and Pandit, 1977).

Table 4. Analysis of variance on retention end loading of plastic polymer in WPC (Wood Plastic Composite products)

\begin{tabular}{|l|c|c|}
\hline \multirow{2}{*}{ Termites species } & & F-calculate \\
\cline { 2 - 3 } & Wood species & Proportion between styrene and vinyl acetate monomer \\
\hline Dry wood termite & $20.73^{* *}$ & $11.30^{* *}$ \\
\hline $\begin{array}{l}\text { Subterranean } \\
\text { termite }\end{array}$ & $43.46^{* *}$ & $31.70^{* *}$ \\
\hline
\end{tabular}

Remarks : ** Highly significant $(\mathrm{P}=0.99)$

Table 5. The retention and loading of plastic polymer (styrene-vinyl acetate co-polymer) in the WPC

\begin{tabular}{|c|c|c|c|c|c|}
\hline \multirow{3}{*}{$\begin{array}{l}\text { Wood } \\
\text { species }\end{array}$} & \multirow{3}{*}{$\begin{array}{c}\text { Mixture } \\
\text { proportion } \\
\text { between styrene } \\
\text { and vinyl } \\
\text { acetate } \\
\text { monomer }\end{array}$} & \multicolumn{2}{|c|}{ Subterranean termite } & \multicolumn{2}{|c|}{ Dry wood termite } \\
\hline & & $\begin{array}{l}\text { Retention } \\
\left(\mathrm{kg} / \mathrm{m}^{3}\right)\end{array}$ & $\begin{array}{c}\text { Polymer loading } \\
(\%)\end{array}$ & $\begin{array}{l}\text { Retention } \\
\left(\mathrm{kg} / \mathrm{m}^{3}\right)\end{array}$ & Polymer loading (\%) \\
\hline & & $(x \pm S d) * \quad D^{1)}$ & $(x \pm S d)^{*} \quad D^{1)}$ & $(x \pm S d) * \quad D^{1)}$ & $(\mathrm{x} \pm \mathrm{Sd})^{*}$ \\
\hline Pine & $60: 40$ & $322.57 \pm 29.22 \mathrm{c}$ & $11.56 \pm 16.59 \mathrm{~d}$ & $366.98 \pm 74.76 \mathrm{~cd}$ & $56.38 \pm 7.40 \mathrm{de}$ \\
\hline Pine & $70: 30$ & $103.56 \pm 8.21 \quad \mathrm{e}$ & $33.63 \pm 10.98 \quad c$ & $477.07 \pm 38.34 \mathrm{ab}$ & $104.76 \pm 22.67 \mathrm{bcd}$ \\
\hline Pine & $80: 20$ & $103.56 \pm 64.20 \mathrm{ab}$ & $50.73 \pm 10.52 b$ & $464.26 \pm 85.84 \mathrm{ab}$ & $69.42 \pm 10.91 \mathrm{cde}$ \\
\hline Pine & $90: 10$ & $426.87 \pm 8.70 \quad$ a & $50.58 \pm 4.82 \quad b$ & $499.36 \pm 73.83 \mathrm{a}$ & $85.52 \pm 7.98 \mathrm{cde}$ \\
\hline Sengon & $60: 40$ & $354.32 \pm 26.48$ bc & $30.64 \pm 9.01 \quad c$ & $295.29 \pm 20.07 \mathrm{de}$ & $153.38 \pm 78.20 \quad b$ \\
\hline Sengon & $70: 30$ & $438.89 \pm 40.50$ & $85.91 \pm 15.82$ a & $420.50 \pm 47.70 \mathrm{abc}$ & $211.72 \pm 65.44 \mathrm{a}$ \\
\hline Sengon & $80: 20$ & $480.66 \pm 46.39$ & $54.99 \pm 13.01 \mathrm{~b}$ & $406.86 \pm 16.76 \mathrm{bc}$ & $223.91 \pm 28.60 \quad a$ \\
\hline Sengon & $90: 10$ & $461.83 \pm 80.97$ & $89.62 \pm 9.91 \quad \mathrm{a}$ & $434.55 \pm 108.98 \mathrm{abc}$ & $115.09 \pm 36.06 \mathrm{bc}$ \\
\hline Rubber-wood & $60: 40$ & $220.60 \pm 70.57 \mathrm{~d}$ & $3.20 \pm 0.69 \quad \mathrm{~d}$ & $262.76 \pm 9.51 \quad \mathrm{e}$ & $44.41 \pm 6.08$ ef \\
\hline Rubber-wood & $70: 30$ & $239.63 \pm 48.34 \mathrm{~d}$ & $11.62 \pm 7.95 \mathrm{~d}$ & $310.00 \pm 40 \quad \mathrm{de}$ & $57.01 \pm 11.01 \mathrm{de}$ \\
\hline Rubber-wood & $80: 20$ & $333.84 \pm 42.21 \mathrm{c}$ & $19.15 \pm 9.65 \mathrm{~cd}$ & $360.28 \pm 29.37 \mathrm{~cd}$ & $61.06 \pm 3.5 \mathrm{de}$ \\
\hline Rubber-wood & $90: 10$ & $350.29 \pm 41.73 \mathrm{bc}$ & $27.96 \pm 7.23$ c & $360.16 \pm 24.54 \mathrm{~cd}$ & $15.68 \pm 30.12 \mathrm{f}$ \\
\hline
\end{tabular}

Remarks : $\mathrm{x}=$ mean value. $\mathrm{Sd}=$ standard deviation

1) Mean values followed by the same letters are not significantly from the others 


\section{B. Efficacy of Styrene Monomers}

\section{Evaluation using dry wood termite}

The durability of WPC against the dry termite was evaluated by determining its weight loss and mortality, followed by the interpretation using the analysis of variance (Table 6 ). The analysis showed that different wood species did not affect significantly on the mortality of dry wood termite. However, the mortality was significantly influenced by the increase of styrene concentration proportion in mixture between styrene and vinyl acetate monomers. The Duncan's test (Table 7 and 8) revealed that the greatest mortality of dry wood termite was obtained in the WPC with the mixture proportion between styrene and vinyl acetate monomers at $80: 20$, respectively (i.e. $98.67 \pm 1.56 \%$ ). The mortality of dry wood termite in the WPC samples was further compared to solid wood pieces treated with impralit $\mathrm{CKB}$ (as the comparison). The results showed that the mortality in WPC samples was practically similar (based on the Duncan's range test) to the one impralit $\mathrm{CKB}$ treated woods pieces, indicating that the use of styrene-vinyl acetate monomers was as effective as impralit $\mathrm{CKB}$ preservative. In comparison to the mortality of dry wood termites in the unpolymerized wood specimens/control (i.e. $40: 5012.68 \%$ ), this $96.68 \%$ figure could be regarded as effective or successful, which was further greater than the lowest mortality limit, i.e. $55 \%$ (Sukman, 1996).

Table 6. Analysis of variance on the weight loss of WPC and the mortality of dry wood termite.

\begin{tabular}{|l|c|c|}
\hline \multirow{2}{*}{ Durability } & \multicolumn{2}{|c|}{ F-calculate } \\
\cline { 2 - 3 } & Wood species & Proportion between styrene and vinyl acetate monomer \\
\hline Mortality & 0.61 & $125.49^{* *}$ \\
\hline Weight loss & $15.78^{* *}$ & $6.16^{*}$ \\
\hline
\end{tabular}

Remarks: **Highly significant $(\mathrm{P}=0,99) \quad$ *significant $(\mathrm{P}=0.95)$

Hadi, et al. (1998) further reported that the mortality of dry wood termites infected 4 wood species (i.e. Salix spp, Alnus spp. Populus spp, and Pinus spp.) after being modified to WPC (using styrene monomers) was $44.9 \%$ in average. Meanwhile, their mortality in those four unmodified wood species (as control) averaged $26.0 \%$. The overall mortality were lower than those resulting from the result of this investigation (i.e. $98.67 \%$ for WPC; and $40.50 \%$ for unmodified/unpolymerized wood). This might indicate that there were occuring some cannibalisms among the termites themselves for research case as conducted by Hadi et al. (1998).

Table 7. Durability of WPC against dry wood termite

\begin{tabular}{|c|c|c|c|c|c|}
\hline \multirow{4}{*}{$\begin{array}{c}\text { Mixture proportion } \\
\text { between styrene and } \\
\text { vinyl acetate } \\
\text { monomers }\end{array}$} & \multicolumn{5}{|c|}{ Durability criteria ${ }^{*}$ ) } \\
\hline & \multirow{2}{*}{$\frac{\text { Mortality }}{(\%)}$} & \multicolumn{2}{|c|}{ Weight loss } & \multirow{3}{*}{$\begin{array}{l}\text { Degree of } \\
\text { protection }\end{array}$} & \multirow{3}{*}{$\begin{array}{l}\text { Class of } \\
\text { resistance }\end{array}$} \\
\hline & & (gram) & $(\%)$ & & \\
\hline & $(X \pm S d) \quad D^{1)}$ & $(X \pm S d)$ & $(\mathrm{X} \pm \mathrm{Sd}) \quad \mathrm{D}^{1)}$ & & \\
\hline \multicolumn{6}{|l|}{ WPC samples } \\
\hline$-60: 40$ & $95.67 \pm 4.25 \mathrm{~b}$ & $0.23 \pm 0.05$ & $1.46 \pm 0.36 \mathrm{ab}$ & 80.00 & IV \\
\hline - $\quad 70: 30$ & $98.33 \pm 3.50 \mathrm{ab}$ & $0.29 \pm 0.06$ & $1.66 \pm 0.46 \mathrm{a}$ & 89.17 & IV \\
\hline$-\quad 80: 20$ & $98.67 \pm 1.56 \mathrm{ab}$ & $0.30 \pm 0.12$ & $1.68 \pm 0.82 \mathrm{a}$ & 92.55 & IV \\
\hline - $\quad 90: 10$ & $98.00 \pm 3.91 \mathrm{ab}$ & $0.21 \pm 0.07$ & $1.28 \pm 0.46 \mathrm{bc}$ & 86.67 & IV \\
\hline $\begin{array}{l}\text { - Impralit CKB } \\
\text { treated wood } \\
\text { Control. }\end{array}$ & $100.0 \pm 0.00 \mathrm{a}$ & $0.13 \pm 0.08$ & $1.00 \pm 0.34 \mathrm{c}$ & 95.00 & IV \\
\hline $\begin{array}{l}\text { Unpolimerized wood } \\
\text { specimens }\end{array}$ & $40.50 \pm 12.68 \mathrm{c}$ & $0.17 \pm 0.07$ & $1.70 \pm 0.70 \mathrm{a}$ & 70.00 & IV \\
\hline
\end{tabular}

Remarks: $\mathrm{X}=$ mean value; $\mathrm{Sd}=\mathrm{Standard}$ deviation;

1) Mean values followed by the same letters are not significantly from the others 
Table 8. Duncan's range test (D) for the weight loss different wood species due to dry wood termite

\begin{tabular}{|l|c|c|c|}
\hline Wood species & $\begin{array}{c}\text { Average of weight loss } \\
(\%)\end{array}$ & $\begin{array}{c}\text { Number of samples(N) } \\
\text { Rubber wood }\end{array}$ Duncan's grouping $^{1)}$ \\
Sengon & 1.168 & 24 & c \\
Pine & 1.795 & 24 & a \\
\hline
\end{tabular}

Remarks: ${ }^{1)}$ mean values followed by the same letters are not significantly difference.

The mixture proportion between styrene and vinyl acetate monomers at proportion 60:40 (i.e. at the lowest styrene portion) proved still effective, since the mortality of the termite reached $95,67 \%$ (Table 7 ) which was yet higher than the control (40,50\%). This might be attributable to the use of terbutyl catalyst at low percentage concentration, which could subsequently poison on the respiration system of the dry wood termite. (Utama, 2000 personal communication). Therefore, it can be inferred that styrene monomers actually did not have any toxic effect on termites (Blout et al., 1949). It is further necessary to note that different wood species (i.e. pine/tusam, sengon, and rubber wood) used for the WPC manufacture did not significantly affect the mortality of termites because these three wood species belong to durability class IV (Mandang and Pandit, 1997).

Table 7 further indicated that the increase in styrene portion correlated negatively with the weight loss. It showed that the greatest weight loss of WPC was in the styrene-vinyl acetate mixtures at $80: 20$ and at $70: 30$ (i.e. $1.68 \%$ and $1.66 \%$ ) suspectively, while the lowest was at $90: 10$ (i.e. $1.28 \%$ ). The occurrence of those interesting phenomena might be partly brought about by the cannibalistic or nectrophagastic behaviors among the termites themselves (Supriana, 1984). Tambunan and Nandika (1989) expressed that in extreme situation the termites could eat the plastic polymer itself.

The ability of styrene to slow down the pace of termites attacking on WPC could also be viewed with respect to the degree of protection (Table 7). The analysis using non-parametric statistics (Kruskal-Wallis' test) revealed that there was a significant negative correlation between the increased proportion of styrene monomers and the wood deterioration. This indicated that the increase in styrene portion caused the decrease in protection level. Meanwhile, the different wood species did not correlate significantly with the wood protection level.

\section{Evaluation using subterranean termite}

Almost similar to the dry wood termite, the durability of WPC attacked by the subterranean termite was evaluated by determining its weight loss and their mortality, followed by the interpretation using analysis of variance (Table 9).

Table 9. Analysis of variance on the weight loss of WPC and the mortality of subterranean termite

\begin{tabular}{|l|c|c|}
\hline \multirow{2}{*}{ Durability } & \multicolumn{2}{|c|}{ F-calculate } \\
\cline { 2 - 3 } & Wood species & Vinyl acetate addition \\
\hline Mortality & $10.33^{* *}$ & $68.86^{* *}$ \\
\hline Weight loss & 2,91 & $29.45^{* *}$ \\
\hline
\end{tabular}

Remarks: ** Highly significant $(\mathrm{P}=0.99)$ 
The analysis (Table 9) showed that different wood species affected significantly to the mortality of subterranean termites but did not have a pronounced effect on the weight loss. However, both the mortality and weight loss were significantly affected by the increase of styrene portion (concentration) in its mixed proportion with vinyl acetate monomer. The more detailed accounts regarding the effect of increasing styrene concentration were performed using the Duncan's range test (Table 10).

Table 10. Durability of WPC against the attack by subterranean termites

\begin{tabular}{|c|c|c|c|c|c|}
\hline \multirow{4}{*}{$\begin{array}{c}\text { Mixture } \\
\text { proportion } \\
\text { between styrene } \\
\text { and vinyl acetate } \\
\text { monomers }\end{array}$} & \multicolumn{5}{|c|}{ Durability criteria*) } \\
\hline & \multirow{2}{*}{$\begin{array}{c}\text { Mortality } \\
(\%)\end{array}$} & \multicolumn{2}{|c|}{ Weight loss } & \multirow{3}{*}{$\begin{array}{l}\text { Degree of } \\
\text { protection }\end{array}$} & \multirow{3}{*}{$\begin{array}{r}\text { Class of } \\
\text { resistance } \\
\left.(\mathrm{A}, \mathrm{B})^{* *}\right)\end{array}$} \\
\hline & & (gram) & $(\%)$ & & \\
\hline & $(\mathrm{X} \pm \mathrm{Sd}) \mathrm{D}^{1)}$ & $(\mathrm{X} \pm \mathrm{Sd})$ & $(\mathrm{X} \pm \mathrm{Sd}) \mathrm{D}^{1)}$ & & \\
\hline \multicolumn{6}{|l|}{ WPC samples } \\
\hline$-60: 40$ & $97.75 \pm 7.37$ & $0.182 \pm 0.078$ & $8.37 \pm 3.48 \quad b c$ & 86.67 & $\mathrm{III}, \mathrm{M}$ \\
\hline$-70: 30$ & $100.0 \pm 0.00$ & $0.205 \pm 0.127$ & $8.31 \pm 4.75 \quad b c$ & 90.83 & IV,M \\
\hline$-80: 20$ & $100.0 \pm 0.00$ & $0.267 \pm 0.111$ & $10.16 \pm 3.67 \quad b$ & 94.17 & IV,N \\
\hline$-90: 10$ & $100.0 \pm 0.00$ & $0.206 \pm 0.087$ & $6.77 \pm 2.85 \mathrm{~cd}$ & 95.00 & IV,M \\
\hline $\begin{array}{c}\text { - Impralit CKB } \\
\text { treated wood }\end{array}$ & $100.0 \pm 0.00$ & $0.087 \pm 0.076$ & $3.79 \pm 2.46 \quad d$ & 96.67 & $\mathrm{IV}, \mathrm{R}$ \\
\hline $\begin{array}{l}\frac{\text { Control }}{\text { Unpolimerized }} \\
\text { wood specimens }\end{array}$ & $49.09 \pm 32.40 \mathrm{~b}$ & $0.414 \pm 0.168$ & $20.61 \pm 5.83$ a & 50.83 & IV,S \\
\hline
\end{tabular}

Remarks: $\mathrm{X}=$ mean value; $\mathrm{Sd}=$ Standard deviation;

1) Mean values followed by the same letters are not significantly from the others

** A = Supriana and Howse (1982) as cited by Martawijaya (1996); B = Sornuwat (1996)

The Duncan's test (Table 10 and 11 ) revealed that the mixture proportions between styrene and vinyl acetate which ranged from $60: 40$ to $90: 10$ did not bring some noticeable changes in the mortality. The mortality can be regarded as high since it reached $97.75 \%$ at $60: 40$ mixed proportion. At the other proportions (70:30 until 90:10), the overall mortalities were $100 \%$ due to the high used of peroxide-terbutyl catalyst which was quite pith (Utama, 2000 personal communication). Besides, the wood species factor could also have a significant role. It follows the mortality of subterranean termites in WPC composed of sengon wood was $87.657 \%$. Meanwhile, the second highest mortality was the one composed of rubber-wood ( $80.874 \%)$, followed by pine wood $(79.125 \%)$ as the lowest. The mortality of subterranean termite in the WPC samples was compared to that in impralit $\mathrm{CKB}$ treated wood pieces. The Duncan's range test showed that the mortality of WPC samples was quite similar to the one of impralit CKB treated wood, indicating the effectiveness of both styrene-vinyl acetate and impralit CKB preservative was similar to each other.

Table 11. Duncan's range test for the mortality of subterranean termite which attacked by three different wood species.

\begin{tabular}{|l|c|c|c|}
\hline \multicolumn{1}{|c|}{ Wood species } & $\begin{array}{c}\text { Average of mortality } \\
(\%)\end{array}$ & $\begin{array}{c}\text { Number of samples } \\
(\mathrm{N})\end{array}$ & Duncan's Grouping \\
\hline Rubberwood & 80.657 & 24 & b \\
\hline Sengon & 87.874 & 24 & a \\
\hline Pine/tusam & 79.125 & 24 & b \\
\hline
\end{tabular}

Remarks: ${ }^{1)}$ mean values followed by the same letters are not significant from the others 
With regard to unpolymerized wood (as a control), the mortality of subterranean termite reached $30.36 \%$ (pine/tusam wood) and $31.38 \%$ (rubber-wood). Those two mortality values were relatively low. Since they were still under the reasonable level (i.e. $45 \%$ ), both pine and rubber-wood in their durability belong to class IV. They did not contain effective extractives which are toxic to the termites. In this respect, the mortality of termites might be brought by their inability to adapt themselves to the environment where food is not available, creating some cannibalistic behavior among them.

About unpolymerized wood sengon species, however, the situation was drastically different. The mortality of termites in this wood species was observed at $87.13 \%$. This high mortality might be caused by specific extractive, presumably composed of among others saponin compounds (Supriana 2000, personal communication). Saponin compounds are foamy aqueous solution that results from a complex reaction between glycoside, steroid hydroxyl aglycon, and dihydroxy linoleic acid. The saponin compounds were also contained in zepote (Manilkara zapote) wood species, which proved its effective resistance against termites and fungi (Fengel and Wegener, 1995).

Weight loss was relatively high for the umpolymerized wood (control) of the three wood species (sengon, pine, and rubber-wood), due to the attacked by subterranean termite (Table 10). This might happen since those three species belong to the class IV with respect to their durability. Further, the data on weight loss as specified by the three species referred to four unpolimerized wood species depicted in Table 12, together with the Duncan's test. It described that the lowest weight loss was at pine wood $(8.425 \%)$, while the highest was at rubber-wood $(10.989 \%)$. The weight loss of sengon wood was intermediate (i.e. $9.593 \%$ ).

Table 12. Duncan's range test for the weight loss of subterranean termite which attacked three different wood species.

\begin{tabular}{|l|c|c|c|}
\hline \multicolumn{1}{|c|}{ Wood species } & $\begin{array}{c}\text { Average weight loss } \\
(\%)\end{array}$ & $\begin{array}{c}\text { Number of samples } \\
(\mathrm{N})\end{array}$ & $\begin{array}{c}\text { Duncan's } \\
\text { Grouping) }\end{array}$ \\
\hline Rubber-wood & 10.989 & 24 & $\mathrm{a}$ \\
Sengon & 9.593 & 24 & $\mathrm{ab}$ \\
Pine/tusam & 8.425 & 24 & $\mathrm{~b}$ \\
\hline
\end{tabular}

Remarks: ${ }^{1}$ mean values followed by the same letters are not significantly from the others

The Duncan's test further revealed that the increase in styrene monomers portion brought about significantly decrease in the weight loss of WPC (Table 10). This indicated that the styrene monomer which further underwent copolymerization with vinyl acetate and to some extent with chemical wood compound were effective in resisting the attacked by subterranean termites. The subsequent Duncan's test showed that mixture proportion with styrene portions at $60 \%$, $70 \%$, and $80 \%$ had their particular mortalities of the termite in the WPC which were similar to each other. This revealed that at $60 \%-80 \%$ of styrene portions, the termite were still able to destroy the plastic polymers to obtain their food (i.e. wood substances).

The ability of styrene monomer in the WPC to resist the attacked by subterranean termite could also be described by the values of its protection degree (Table 10). The evaluation using non-parametric statistics (i.e. the Kruskal-Wallis's test) revealed that there was a significant correlation between mixture proportions of monomers (Styrene + vinyl acetate) and wood deterioration ( $\mathrm{H}$-value, i.e. 30.22 greater than $\mathrm{H}$-table, i.e. 11.67), which showed that the increase 
in styrene portion brought about higher protection level. Meanwhile, different wood species did not appear to correlate significantly with protection level (H-value, i.e. 5.29 less than $\mathrm{H}$-table, i.e. 11.67).

\section{CONCLUSION}

The use of styrene with addition of vinyl acetate monomer at the proportion as low as 60:40 resulted in the WPC which was able to resist the attacked by dry wood termite (C. cynocephalus Light.) as well as subterranean termite (C. curvignathus Holmgren.).

Mortality of the dry wood termite and subterranean termite in the WPC was exceedingly much greater than those in unpolymerized wood. The mortality of termite in WPC samples was comparable to the one in impralit $\mathrm{CKB}$ treated wood.

In general, the results of this research suggested the manufacture of WPC using mixed monomers of styrene and vinyl acetate has a positive prospect to improve durability of wood against the deteriorating organisms.

\section{ACKNOWLEDGEMENTS}

Thanks to Didik M. Sudika and Endang Sudrajat for their valuable assistance to collect subterranean termites.

\section{REFERENCES}

AWPA. 1972. Standard Method for Laboratory Evaluation to Determine Resistance to Subterranean Termites. American Wood Preservative's Association, Woodstock, Md. Blout, E.R., W.P. Hohenstein and H. Mark. 1949. Monomers. Interscience Publishers, Inc. New York. Dirgantara.,U. 1988. Pengaruh dosis iradiasi dan posisi bambu betung (Dendrocalamus asper) yang diimpregnasi polimerisasi dengan sterina terhadap serangan jamur pelapuk kayu (Schizophyllum commune Fr.). Skripsi Jurusan THH Fahutan IPB. Tidak dipublikasikan.

Fengel, D. and G. Wegener. 1995. Kayu: Kimia, Ultra structure, Reaksi-reaksi (Terjemahan oleh Harjono, S). Gadjah Mada University Press. Yogyakarta.

Hadi,Y.S., D.S. Nawawi, E.N. Herliyana, and M. Lawniczak. 1998. Termites Attack Resistance of Four Polystyrene-Impregnated Wood from Poland. Forest Product Journal.48(9):60-62.

Mandang, Y.I and I.K.N. Pandit. 1997. Pedoman Identifikasi Jenis Kayu di Lapangan. Yayasan Prosea, Pusat Diklat Pegawai dan SDM Kehutanan. Bogor.

Martawijaya, A. 1996. Keawetan Kayu dan Faktor yang Mempengaruhinya. Petunjuk Teknis. Pusat Penelitian dan Pengembangan Hasil Hutan dan Sosial Ekonomi Kehutanan. Balitbang Kehutanan, Bogor.

Sajidin. 1977. Pengaruh tingkat konsentrasi urea dan system impregnasi pada polimerisasi radiasi terhadap sifat fisis dan mekanis bamboo betung. Skripsi Jurusan THH Fahutan IPB. Tidak dipublikasikan.

Sornuwat, Y. 1996. Studies on Damage of Constructions Caused by Subterranean Termites and Its Control in Thailand. Paper in Lab. BHH Pau Ilmu Hayat. Not Published.

Sukman, A. 1996. Keawetan kayu karet vinil asetat terhadap rayap kayu kering (Cryptotermes cynocephalus Light.) dan bubuk kayu kering (Heterobostrychus aequalis Wat.). Skripsi Jurusan Teknologi Hasil Hutan. Fakultas Kehutanan, IPB. Tidak dipublikasikan.

Supriana, N. 1984. Perilaku Rayap. Pusat Penelitian dan Pengembangan Hasil Hutan, Bogor. Susanti, U. 1997. Ketahanan kayu karet (Hevea brasilliensis Muell.Arg.) terpolimerisasi terhadap serangan jamur pelapuk (Schizophyllum commune Fr.). Skripsi pada Jurusan MNH Fahutan IPB. Tidak diterbitkan.

Tambunan, B. and D. Nandika. 1989. Deteriorasi kayu oleh faktor biologis. Pusat Antar Universitas Bioteknologi IPB. Bogor. 